OPEN ACCESS

Edited by:

Xavier Mayali,

Lawrence Livermore National

Laboratory, USA

Reviewed by:

Ingrid Obernosterer,

Observatoire Océanologique de Banyuls-sur-Mer - Centre National de la Recherche Scientifique, France

Guang Gao,

Nanjing Institute of Geography and

Limnology (CAS), China

*Correspondence:

Marilou P. Sison-Mangus

msisonma@ucsc.edu

Specialty section:

This article was submitted to

Aquatic Microbiology,

a section of the journal

Frontiers in Microbiology

Received: 10 May 2016

Accepted: 29 August 2016

Published: 12 September 2016

Citation:

Sison-Mangus MP, Jiang S, Kudela RM and Mehic S (2016) Phytoplankton-Associated Bacterial

Community Composition and Succession during Toxic Diatom Bloom and Non-Bloom Events.

Front. Microbiol. 7:1433.

doi: 10.3389/fmicb.2016.01433

\section{Phytoplankton-Associated Bacterial Community Composition and Succession during Toxic Diatom Bloom and Non-Bloom Events}

\author{
Marilou P. Sison-Mangus ${ }^{1 *}$, Sunny Jiang ${ }^{2}$, Raphael M. Kudela ${ }^{1}$ and Sanjin Mehic ${ }^{1}$ \\ ${ }^{1}$ Department of Ocean Sciences and Institute of Marine Sciences, University of California, Santa Cruz, Santa Cruz, CA, USA, \\ ${ }^{2}$ Department of Civil and Environmental Engineering, University of California, Irvine, Irvine, CA, USA
}

Pseudo-nitzschia blooms often occur in coastal and open ocean environments, sometimes leading to the production of the neurotoxin domoic acid that can cause severe negative impacts to higher trophic levels. Increasing evidence suggests a close relationship between phytoplankton bloom and bacterial assemblages, however, the microbial composition and succession during a bloom process is unknown. Here, we investigate the bacterial assemblages before, during and after toxic and nontoxic Pseudo-nitzschia blooms to determine the patterns of bacterial succession in a natural bloom setting. Opportunistic sampling of bacterial community profiles were determined weekly at Santa Cruz Municipal Wharf by 454 pyrosequencing and analyzed together with domoic acid levels, phytoplankton community and biomass, nutrients and temperature. We asked if the bacterial communities are similar between bloom and non-bloom events and if domoic acid or the presence of toxic algal species acts as a driving force that can significantly structure phytoplankton-associated bacterial communities. We found that bacterial diversity generally increases when Pseudonitzschia numbers decline. Furthermore, bacterial diversity is higher when the low-DA producing $P$. fraudulenta dominates the algal bloom while bacterial diversity is lower when high-DA producing $P$. australis dominates the algal bloom, suggesting that the presence of algal toxin can structure bacterial community. We also found bloom-related succession patterns among associated bacterial groups; Gamma-proteobacteria, were dominant during low toxic $P$. fraudulenta blooms comprising mostly of Vibrio spp., which increased in relative abundance (6-65\%) as the bloom progresses. On the other hand, Firmicutes bacteria comprising mostly of Planococcus spp. (12-86\%) dominate during high toxic $P$. australis blooms, with the bacterial assemblage showing the same bloomrelated successional patterns in three independent bloom events. Other environmental variables such as nitrate and phosphate and temperature appear to influence some low abundant bacterial groups as well. Our results suggest that phytoplankton-associated bacterial communities are strongly affected not just by phytoplankton bloom in general, but also by the type of algal species that dominates in the natural bloom.

Keywords: algal bloom, Pseudo-nitzschia, diatom, bacteria, Vibrio, Planococcus, nutrients, domoic acid 


\section{INTRODUCTION}

Phytoplankton plays an important role in global carbon cycling by consuming carbon dioxide from the atmosphere for photosynthesis and sequestering the fixed carbon as cells sink down into the deep ocean. Phytoplankton bloom, happening either in the coast, upwelling regions or open ocean, not only provides organic materials to the higher trophic food web but also provides photosynthate-released dissolved organic matter (Larsson and Hagstrom, 1979) and organic suspended matter for bacterial attachment and subsequent degradation by heterotrophic bacterial communities (Smith et al., 1995). Azam et al. (1983) reported that bacterial biomass and production is tightly coupled with phytoplankton biomass. With the use of molecular tools, many workers discovered that bacterial communities change in composition as algal bloom peak and decline (Riemann et al., 2000; Teeling et al., 2012; Klindworth et al., 2014). Bacterial groups such as Alphaproteobacteria, Gamma-proteobacteria and Flavobacteria are often reported as the dominant free-living bacterioplankton during algal bloom (reviewed in Buchan et al., 2014). It is still unclear, however, if phytoplankton-associated bacteria undergo the same pattern and if bacterial composition and succession is being influenced by the algal species in bloom or if the phytotoxins produced by harmful algae also play a role in structuring bacterial communities during algal bloom.

Many bacteria associate with phytoplankton (Schafer et al., 2002; Grossart et al., 2005; Sison-Mangus et al., 2014) and are often seen attached on healthy or dying cells (Kaczmarska et al., 2005; Gardes et al., 2011; Mayali et al., 2011; Smriga et al., 2016), as they feed off on the released dissolved organic matter, breaking down the dead algal cell (Bidle and Azam, 1999) or actively killing the phytoplankton (Mayali and Azam, 2004). Phytoplankton cultivates close associations with bacteria as imposed by their dependence on vitamins, recycled nutrients, photooxidation of assimilable iron or amino acids (Croft et al., 2005; Amin et al., $2009,2015)$. On the other hand, phytoplankton varies in terms of biochemical composition, organic excretions (Reitan et al., 1994; Hellebust, 1980; Bjornsen, 1988) or phytotoxins (Doucette et al., 1998), which may act as selective agents for bacterial types with algal-attached lifestyle. It is therefore interesting to determine if bloom-forming phytoplankton species can also facilitate the dominance of different bacterial groups during bloom events.

In this study, we focus on the domoic acid producing Pseudo-nitzschia (Pn) and studied the phytoplankton-associated bacterial community from four independent natural bloom events. We asked what bacterial groups dominate in bloom events formed by different Pseudo-nitzschia species. We determined how bacterial composition changes before, during and after the decline of Pseudo-nitzschia bloom, as it was replaced or co-dominated by other phytoplankton species. Aside from phytoplankton biomass (as chlorophyll $a$ ), we also looked at environmental variables such as nutrients (nitrate, phosphate, silicate, urea, and ammonium), and temperature to determine if these physical factors also play a role in bacterial succession.
Our results indicated that bacterial composition and structure are strongly influenced by the Pseudo-nitzschia species in bloom and domoic acid can play a role in limiting bacterial diversity.

\section{MATERIALS AND METHODS}

\section{Plankton Tow, Bacteria Sampling and Environmental Data Collection and Processing \\ Sampling Site}

The samples used in the study were subsamples from the weekly monitoring of harmful algal bloom adjacent to Santa Cruz Municipal Wharf $\left(36.9633^{\circ} \mathrm{N}, 122.0172^{\circ} \mathrm{W}\right)$ in Monterey Bay, California, one of the ocean observing sites in Central and Northern California (CeNCOOS). The site was established to monitor the presence, abundance and population dynamics of red tide forming species, where weekly monitoring of nutrients, environmental parameters, phytoplankton abundance, chlorophyll $a$ and fecal indicator bacteria are measured. Water condition in Monterey Bay is characterized by seasonal upwelling that brings low temperature, high salinity nutrientrich water from approximately February to August, followed by an oceanic period characterized by upwelling relaxation in August to mid-November. In winter (mid November-mid February), the Davidson Current surfaces along the coast and brings in relatively warm, high salinity, nutrient-rich water (Skogsberg, 1936; Skogsberg and Phelps, 1946; Wyllie and Lynn, 1971; Pennington and Chavez, 2000). Upwelled water together with agricultural run-offs from numerous watersheds feed nutrients into the bay to support massive phytoplankton blooms (Kudela and Chavez, 2004; Kudela et al., 2008; Fischer et al., 2014). Different Pseudo-nitzschia species bloom in regular pattern in the bay since their initial discovery in 1991 (Buck et al., 1992; Scholin et al., 2000; Lane et al., 2009).

\section{Water and Phytoplankton Sampling}

Vertical phytoplankton tows are normally collected in the early morning at an integrated depth of $1-10 \mathrm{ft}$ depth $(5 \times 10 \mathrm{ft}$ vertical effort) using a $20 \mu \mathrm{m}$ mesh with a cod end volume of $300 \mathrm{~mL}$. A 2-L Niskin bottle was used to collect water samples at the same integrated depth and used for nutrients and chlorophyll analysis. Temperature was measured immediately after water collection. For this study, opportunistic sampling was carried out at different phases of the bloom, from the beginning and end of the bloom in November to December 2010 (Fall) and peak and demise in March (Spring), July and August 2011 (Summer). Bloom phases were categorized based on total number of Pseudo-nitzschia cells per liter and are as follows: No bloom - 0 to 10000; Low Bloom 10, 001 to 30,000; Medium bloom - 30,001 - 100, 000; High Bloom - 100001 to 300000; Highest Bloom- >300, 000. Closure of shellfish harvesting commonly occurs when DA-producing Pseudo-nitzschia bloom is seen at 100, 000 cells $\mathrm{L}^{1}$ (Bates et al., 1998). 


\section{Algal Counting, Domoic Acid, Chlorophyll and Nutrients Measurement}

Algal counts were initially assessed microscopically based on relative percentage abundance followed by counting of total Pseudo-nitzschia cells by microscopy and counting of toxic Pseudo-nitzschia species using DNA fluorescent in-situ hybridization (FISH) (Miller and Scholin, 1998). Domoic acid in bloom samples were measured using LC/MS method as described in Lane et al. (2010). Briefly, water samples were filtered on GFF filters and stored in $-80^{\circ} \mathrm{C}$. Ice-thawed filters were submerged in $3 \mathrm{~mL} 10 \% \mathrm{MeOH}$ and intermittently sonicated on ice for $30 \mathrm{sec}$ at an output power of $<8$ Watts. The thick suspension was syringe filtered with $0.22 \mu \mathrm{m}$ Millex PVDF membrane (EMD Millepore, USA), and stored in $-80^{\circ} \mathrm{C}$ until further processing. DA samples were purified prior to LC/MS analysis. Steps are as follows: DA samples were first prepared by adding $0.5 \mathrm{~mL}$ of formic acid and $\mathrm{MeOH}$ diluted with Milli-Q water (2:5:93 ratio) and briefly vortexed. The solid phase extraction (SPE) columns (Agilent, USA) were first conditioned with $10-\mathrm{mL} 100 \% \mathrm{MeOH}$ followed by 10 $\mathrm{mL}$ Milli-Q water under gentle vacuum of $10 \mathrm{Pka}$, and not letting the SPE columns to dry. After addition of DA samples to the conditioned columns, the sample tubes were rinsed with $4-\mathrm{mL} 0.5 \%$ aqueous formic acid, and combined with the samples already in the columns. An additional step of adding $4-\mathrm{mL} 0.15 \%$ formic acid was carried out. DA in the columns were recovered with $3 \mathrm{~mL} 50 \% \mathrm{MeOH}$ and transferred to a pre-weighed glass vial for storage at $4^{\circ} \mathrm{C}$ until analysis of DA via LC/MS (described in Lane et al., 2010). Nutrient samples (nitrate + nitrite hereafter referred to here as nitrate, phosphate and silicate) pre-filtered in GF/F filters (nominal size of $0.7 \mu \mathrm{m}$ ) were analyzed using a Lachat QuikChem 8500 Flow Injection Analyst System and Omnion 3.0 software (Lachat Instruments; Hach Company, Loveland, CO, USA) following the method described in Smith and Bogren (2001) and Knepel and Bogren (2002). Ammonium and urea were analyzed with the method of Holmes et al. (1999) and Price and Harrison (1987), respectively. Chlorophyll $a$ analysis was carried out following the non-acidification method described in Welschmeyer (1994).

\section{Bacteria Sampling}

Phytoplankton tow samples were first pre-filtered with 300$\mu \mathrm{m}$ mesh net (bleached and UV-exposed) to remove debris and zooplankton. Three of $30-\mathrm{mL}$ tow samples were filtered with sterile $5 \mu \mathrm{m}$ Durapore filters (EMD Millipore, USA) and washed with sterile seawater to filter out unassociated bacteria. Algae were collected by resuspending filters in $10 \mathrm{ml}$ of PCR water. Samples were then pelleted via centrifugation at $3000 \times g$ for $10 \mathrm{~min}$. Algal pellets were finally resuspended in $500 \mu \mathrm{L}$ of sterile TE buffer and stored at $-80^{\circ} \mathrm{C}$. For sequencing, raw samples were sent to Research and Testing Laboratory (Lubbock, TX, USA) for 454 pyrosequencing using the universal primers Yellow939F and Yellow1492R. Sample preparation for sequencing and sequencing methods are described in Sison-Mangus et al. (2014).

\section{Pseudo-nitzschia Isolation and Genotyping}

Single cells of Pseudo-nitzschia were manually isolated from bloom samples with a microcapillary tip from a sterile glass Pasteur pipette. Prior to cell isolation, an aliquot of the prefiltered tow sample was filtered with $100 \mu \mathrm{m}$ nylon mesh (bleached and UV-sterilized) and washed two times with autoclaved-sterilized $0.2 \mu \mathrm{m}$ filtered seawater (FSW) to remove unassociated bacteria. Algal suspension was diluted with FSW. Isolated cells were washed 10 times with FSW, inoculated in $\mathrm{F} / 10$-Se medium and incubated under growth conditions of $12: 12$ photoperiod, $15^{\circ} \mathrm{C}$ and $80 \mu \mathrm{E} \mathrm{m} \mathrm{m}^{-2}$ in an algal incubator. Successful isolates were transferred in F/2-SE medium for maintenance. The Pseudo-nitzschia cultures were identified by morphology using light microscopy and genotyped by sequencing the $18 \mathrm{~S}$ rRNA gene.

Pseudo-nitzschia genomic DNA was extracted with PowerSoil DNA Isolation Kit (MoBio Laboratories Inc., Solana Beach, CA, USA). P. pungens and $P$. fraudelenta were amplified with primer pairs 1360F (5'-GCGTTGAT/ATACGTCCCTGCC- $3^{\prime}$ ) and ITS055R (5'-CTCCTTGGTCCGTGTTTCAAGACGGG-3'), while $P$. australis and $P$. multiseries was amplified with primer pairs 18S-F (5'-CTGCGGAAGGATCATTACCACA-3') and ITS055R using EconoTaq DNA Polymerase (Lucigen, Middleton, WI, USA) under the following PCR conditions: $94^{\circ} \mathrm{C}$ for $2 \mathrm{~min}, 30$ cycles of $94^{\circ} \mathrm{C}$ for $1 \mathrm{~min}, 55^{\circ} \mathrm{C}$ for $1 \mathrm{~min}$, and $72^{\circ} \mathrm{C}$ for $1.5 \mathrm{~min}$ and $72^{\circ} \mathrm{C}$ for $10 \mathrm{~min}$ extension. The products were sent to a service facility (Laragen Inc, Culver, CA, USA) for direct sequencing after labeling with the Big Dye Terminator with AmpliTaq FS Sequencing Kit (Applied Biosystems, Foster City, CA, USA) using the PCR primers as sequencing primers.

\section{Sequence Data Processing}

Short sequence reads (length $<150 \mathrm{bp}$ ), low quality sequences (score <25; Huse et al., 2007) and any non-bacterial ribosome sequences and chimeras (Gontcharova et al., 2010) were removed prior to sequence analysis using Quantitative Insights Into Microbial Ecology (QIIME 1.8) pipeline (Caporaso et al., 2010b). Uclust (Edgar, 2010) was used in picking operational taxonomic units (OTUs) based on clustering sequences at 97\% similarity. Representative sequences were aligned using Pynast (Caporaso et al., 2010a) using Greengenes core alignment as a reference (DeSantis et al., 2006). OTUs were assigned based on RDP classifier 2.2 (Wang et al., 2007), while the assignment of abundant bacterial taxon at the genus level was performed using BLAST [Altschul et al., 1990, E-value 10_20 (megablast only); minimum coverage 97\%; minimum pairwise identity 90-97\%]. Singletons and chloroplast sequences were filtered from the OTU table prior to bacterial diversity analyses. A phylogenetic tree of the OTUs was generated and viewed with Fast Tree 2.1.3 (Price et al., 2010).

The raw sequencing reads have been deposited at the NCBI Short Read Archive under BioProject ID PRJNA329303 with the following BioSample accession numbers: SAMN05410841 (Tow 
11.17.10), SAMN05410842 (Tow_12.01.10), SAMN0541084 (Tow_12.08.10), SAMN05410844 (Tow_12.15.10), SAMN054 10845 (Tow_12.22.10), SAMN05410846 (Tow_03.16.11), SAMN 05410847 (Tow_03.23.11), SAMN05410848 (Tow_07.06.11), SAMN05410849 (Tow_07.13.11), SAMN05410850 (Tow_ 08.24.11), SAMN05410851 (Tow_08.31.11).

\section{Statistical Analysis}

Correlation tests using multivariate non-parametric Spearman rank's correlation coefficient and Student's $t$-test were carried out using the software JMP 12.0.

\section{RESULTS}

\section{Phytoplankton Community at Different Phases of Pseudo-nitzschia Bloom}

Opportunistic sampling was done in Santa Cruz Municipal Wharf during the occurrence of Pseudo-nitzschia bloom. In mid-November 2010, phytoplankton diversity was high with the community being co-dominated by Pseudo-nitzschia, Prorocentrum and Ceratium (Figure 1). The assemblage changed into mostly Pseudo-nitzschia as the massive bloom progressed for 4 weeks. At the end of the bloom at week 5, there was an equal presence between Pseudo-nitzschia and dinoflagellates. Single algal cell isolations followed by genotyping indicated that $P$. fraudulenta dominated the Pseudo-nitzschia community and FISH probing and counting indicated that $P$. australis were also present in small number (Figure 2C).

In 2011, an early spring bloom of $P$. australis occurred in mid-March, but this bloom did not last as the population of the dinoflagellate Ceratium co-dominated the following weeks. In July 2011, a small bloom of $P$. australis was seen together with Chaetoceros and Eucampia, but noticeably decreased the following weeks and was replaced by higher diversity of phytoplankton with the co-dominance of Guinardia, Chaetoceros and Eucampia. In August 2011, a massive P. australis bloom occurred that lasted for 3 weeks. The algal community shifted and co-dominated both by the dinoflagellates Protoperidinium and $P$. australis during the fourth week, but phytoplankton biomass has decreased. P. australis were the dominant Pseudonitzschia species in 2011 (Figure 2C), with a small number of P. multiseries (3450 cells/ L) seen on March 23, 2011. Chlorophyll levels for the data gathered during opportunistic sampling showed that overall phytoplankton biomass range from 2.8 to $11.7 \mathrm{mg} \mathrm{m}^{-3}$, with the highest chlorophyll level observed in 2010 during the bloom dominated by $P$. fraudulenta, where positive correlation existed (Spearman rho $=0.76, p<0.006$ ). Temperature range during late Fall 2010 sampling was between $11-14^{\circ} \mathrm{C}$, while it was $12^{\circ} \mathrm{C}$ during Spring 2011 and $14-15^{\circ} \mathrm{C}$ in the Summer 2011. There was no correlation seen between temperature and chlorophyll level, or between temperature and total Pseudo-nitzschia cells, Pseudonitzschia species or DA. Additionally, a negative correlation of temperature with nitrate was seen (Spearman rho $=-0.84$, $p<0.001)$.

\section{Nutrients, Pseudo-nitzschia Number and DA Level Are De-coupled during Pseudo-nitzschia Algal Bloom}

We looked at the correlation between nutrients and total Pseudonitzschia cell number and the presence of toxic Pseudo-nitzschia species (Figure 2). Interestingly, none of the nutrients (urea, ammonium, nitrate, phosphate, and silicate) were correlated with cell abundance of Pseudo-nitzschia in a natural bloom and the five nutrients did not show any correlation with $P$. fraudulenta, $P$. australis, $P$. multiseries cell numbers (data not shown). Notably, DA level was positively correlated only with $P$. australis cell numbers (Spearman rho $=0.69, p<0.02$ ) but not with total $P$ seudo-nitzschia number or with $P$. fraudulenta cell number, even though this low-toxin producing species was present in very high numbers in 2010 bloom (Figures 2B,C). Likewise, temperature did not show any correlation with total Pseudo-nitzschia cell numbers, $P$. fraudulenta or $P$. australis cell numbers or with any of the aforementioned parameters, except for nitrate, to which it showed negative correlation (Spearman rho $=-0.84, p<0.001$ ).

\section{High DA-Producing $P$. australis Negatively Affects Bacterial Diversity in Natural Bloom}

A total of 83,284 clean $16 \mathrm{~S}$ rDNA sequences was obtained from 11 samples belonging to four Pseudo-nitzschia bloom events captured at different bloom phases (before, during and at the decline phases in 2010 and during and at decline phases in 2011). These sequences were assigned into 4732 OTUs ( $>97 \%$ ID), but reduced to 2621 OTUs after removing singletons and chloroplast sequences. The remaining OTUs were analyzed for bacterial diversity in every sample. Statistical analysis indicated that there was no significant correlation between phytoplankton biomass (i.e., chlorophyll $a$ ) and bacterial diversity (measured as Observed number of OTUs, Phylogenetic diversity, Shannon and Chao indices) suggesting that total phytoplankton biomass did not influence bacterial diversity (Table 1).

We determined if bacterial diversity was specifically affected by the presence of Pseudo-nitzschia bloom. Although bacterial diversity was lower during Pseudo-nitzschia bloom (Figure 3A), comparison of four bacterial indices (calculated at 2000 sequences depth) between Pseudo-nitzschia bloom and no-bloom suggested that bacterial diversity was not significantly different between the two events (Student's $t$-test, $p>0.05$ ). However, the correlation analysis at the Pseudo-nitzschia species level indicated that the presence of high DA-producing $P$. australis negatively affected bacterial diversity (Table 1). Bacterial diversity was generally lower when the Pseudo-nitzschia bloom was dominated by $P$. australis versus $P$. fraudulenta (Figure 3B). Because low DA-producing $P$. fraudulenta were only present in 2010 , correlation analysis for $P$. fraudulenta number versus bacterial diversity was carried out on this small data set. We found that as $P$. fraudulenta increased in number, bacterial diversity also declined (Table 1). Also, closer inspection indicated that bacterial diversity was lower as DA accumulated, due to increasing number of $P$. fraudulenta and the combined presence of $P$. australis 


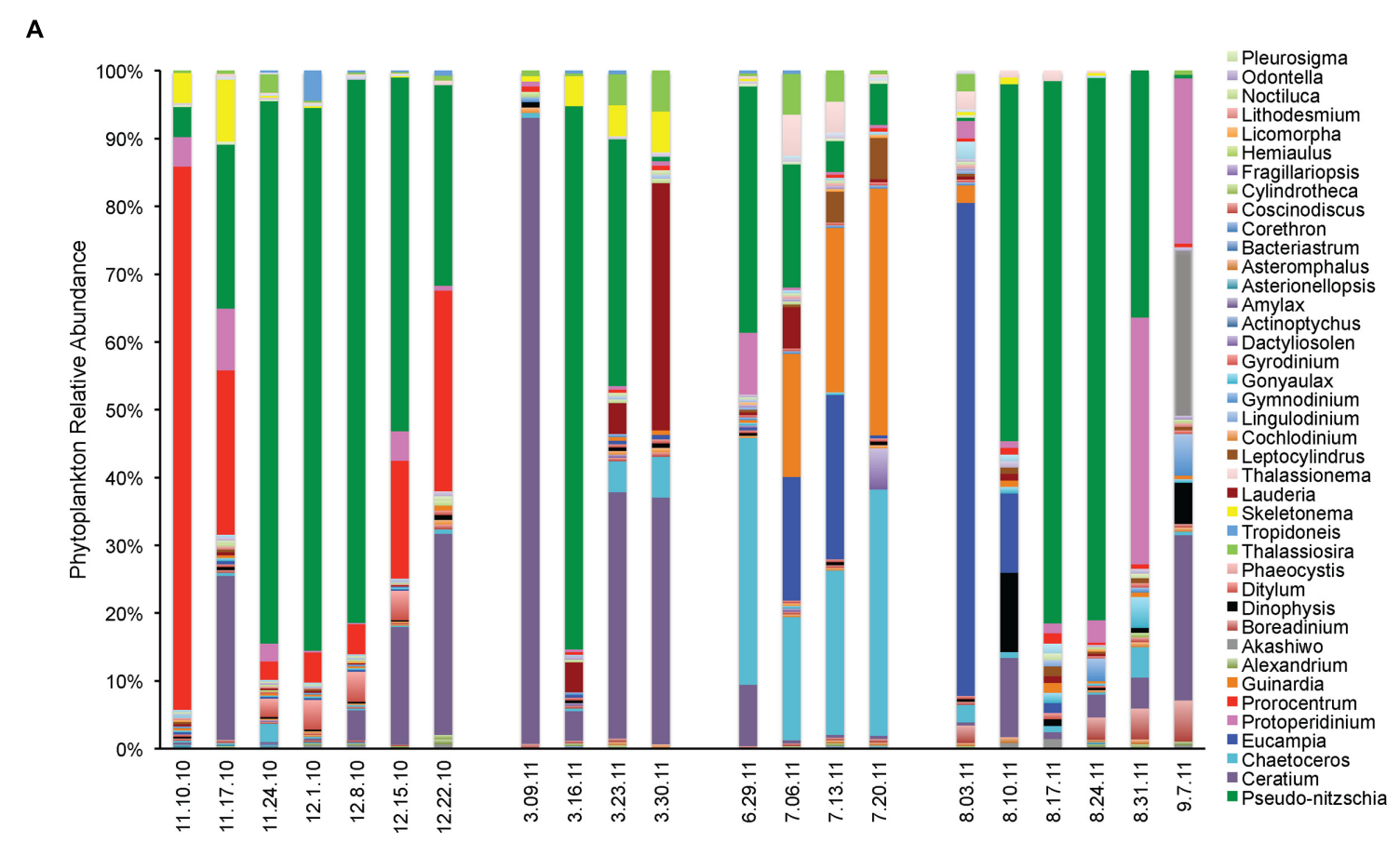

B

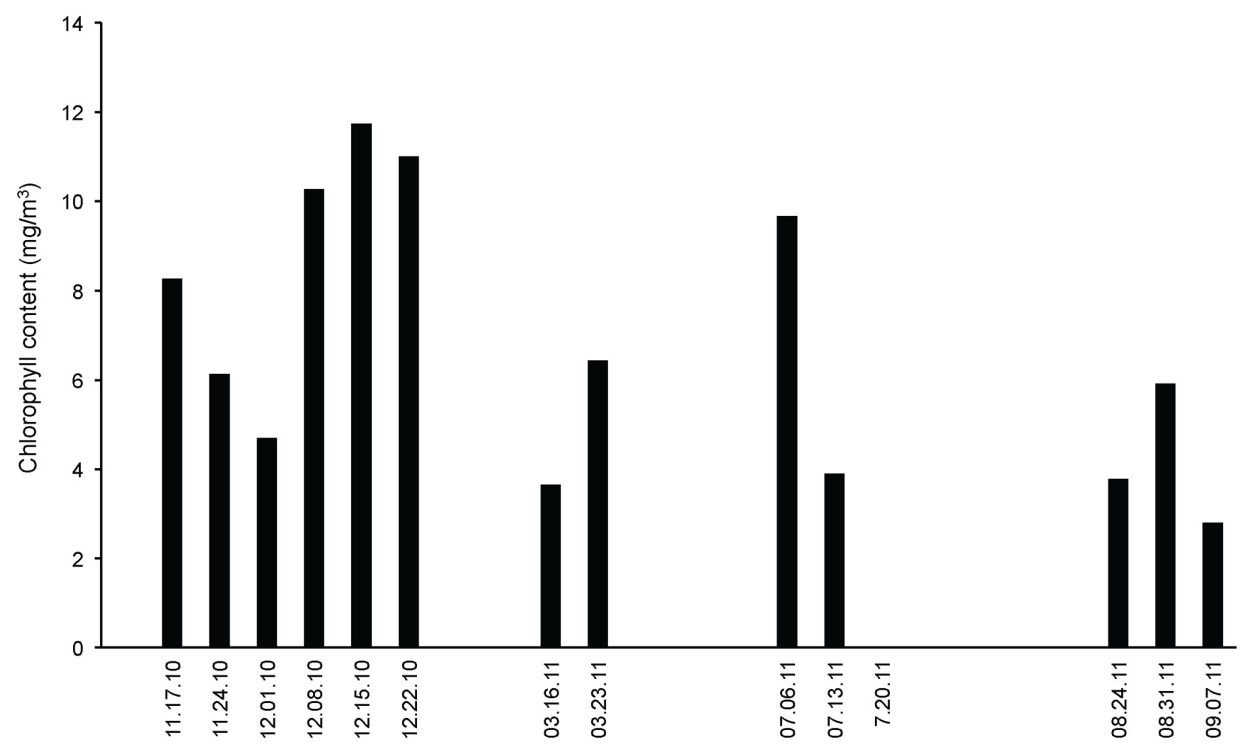

FIGURE 1 | Phytoplankton community assemblage before, during and after Pseudo-nitzschia bloom events in 2010 and 2011. (A) Phytoplankton relative abundance for each algal group assessed by microscopy. (B) Phytoplankton biomass expressed as total chlorophyll content.

(Figures 3B and 2C). Bacterial diversity also negatively correlated with temperature while it positively correlated with phosphate and nitrate concentrations (Table $\mathbf{1}$ ).

\section{Dominant Bacterial Groups Vary with Different Pseudo-nitzschia Bloom Events}

We asked which bacterial groups dominate before, during or at the decline phase of Pseudo-nitzschia bloom and looked at other environmental variables that may facilitate their dominance. At least ten bacterial phyla (or class) were frequently found associating with phytoplankton during non-bloom events (Figure 4). However, during Pseudo-nitzschia bloom events, only a few bacterial phyla dominated the bacterial assemblages (Figure 4A) and these bacterial assemblages changed depending on the dominant Pseudo-nitzschia species that comprised the bloom. In 2010, Gamma-proteobacteria (65-85\%) were prevalent 




FIGURE 2 | Pseudo-nitzschia cell numbers, domoic acid (DA) and nutrient concentrations before, during and after Pseudo-nitzschia bloom events in 2010 and 2011. (A) Urea, ammonium, nitrate, phosphate, and silicate concentrations. (B) Particulate domoic acid content. (C) Total number of Pseudo-nitzschia cells (gray) superimposed with the $P$. australis cell numbers (red).

when a low-toxic species, $P$. fraudulenta, dominated the Pseudonitzschia populations (Spearman rho $=-0.79, p<0.004$ ) and decreased in relative abundance during $P$. australis bloom (0-38\%). These bacterial groups were also correlated with nitrate concentrations (Spearman rho $=-0.64, p<0.035$ ). The Firmicutes phyla (20-95\%) dominated in 2011 during high toxin blooms and were highly correlated with $P$. australis cell number (Spearman rho $=-0.72, p<0.013)$. Bacteroidetes $(0-$ $32 \%)$ and Epsilonbacteria (0-19\%) groups were mostly present in the background but were not significantly correlated with the environmental conditions studied; Bacteroidetes, however, had higher relative abundance during non-Pn bloom events (14-32\%) than during Pn bloom (0-9\%; Figure 4A). Similarly, Alphaproteobacteria were also always present but their abundance was negatively correlated with the total number of Pseudo-nitzschia cells especially in the presence of high number of $P$. fraudulenta (1-3\% vs. $15-20 \%$ during low or no Pn-bloom; Spearman rho $=-0.77, p<0.006)$. On the contrary, Fusobacteria $(1-2 \%)$ were only present in 2010 bloom and positively correlated with $P$. fraudulenta abundance (Spearman rho $=-0.79, p<0.004$ ). Bacterial groups that were present but in low relative abundance such as the Chloroflexi (0-3\%), Acidobacteria (0-12\%), and Betaproteobacteria (0-4\%) groups were negatively correlated with temperature (Spearman rho $=-0.60-0.79, p<0.05$ ). Actinobacteria (0-6\%), another low abundant bacterial group,

TABLE 1 | Correlations between environmental variables and bacterial diversity as measured by four diversity indices.

\begin{tabular}{|c|c|c|}
\hline & Spearman rho & $p$-level \\
\hline \multicolumn{3}{|c|}{ Phyto biomass (chl a) vs. bacterial diversity } \\
\hline No. of OTUs & 0.40 & 0.223 \\
\hline Shannon index & 0.08 & 0.811 \\
\hline Phylo. diversity index & 0.40 & 0.223 \\
\hline Chao index & 0.40 & 0.223 \\
\hline \multicolumn{3}{|c|}{ Total no. of Pn cells vs. bacterial diversity } \\
\hline No. of OTUs & 0.14 & 0.689 \\
\hline Shannon index & -0.13 & 0.709 \\
\hline Phylo. diversity index & 0.15 & 0.670 \\
\hline Chao index & 0.14 & 0.689 \\
\hline \multicolumn{3}{|c|}{ P. australis no. vs. bacterial diversity } \\
\hline No. of OTUs & -0.85 & 0.001 \\
\hline Shannon index & -0.62 & 0.043 \\
\hline Phylo. diversity index & -0.85 & 0.001 \\
\hline Chao index & -0.85 & 0.001 \\
\hline \multicolumn{3}{|c|}{$P$. fraudulenta no. vs. bacterial diversity } \\
\hline No. of OTUs & -0.90 & 0.037 \\
\hline Shannon Index & -0.70 & 0.1881 \\
\hline Phylo. diversity index & -1.0 & $<0.0001$ \\
\hline Chao index & -0.90 & 0.037 \\
\hline \multicolumn{3}{|c|}{ Temperature vs. bacterial diversity } \\
\hline No. of OTUs & -0.65 & 0.032 \\
\hline Shannon index & -0.78 & 0.005 \\
\hline Phylo. diversity index & -0.55 & 0.077 \\
\hline Chao index & -0.65 & 0.032 \\
\hline \multicolumn{3}{|c|}{ Nitrate vs. bacterial diversity } \\
\hline No. of OTUs & 0.70 & 0.017 \\
\hline Shannon index & 0.72 & 0.013 \\
\hline Phylo. diversity index & 0.64 & 0.035 \\
\hline Chao index & 0.70 & 0.017 \\
\hline \multicolumn{3}{|c|}{ Phosphate vs. bacterial diversity } \\
\hline No. of OTUs & 0.65 & 0.032 \\
\hline Shannon index & 0.60 & 0.052 \\
\hline Phylo. diversity index & 0.55 & 0.082 \\
\hline Chao index & 0.65 & 0.032 \\
\hline
\end{tabular}


A
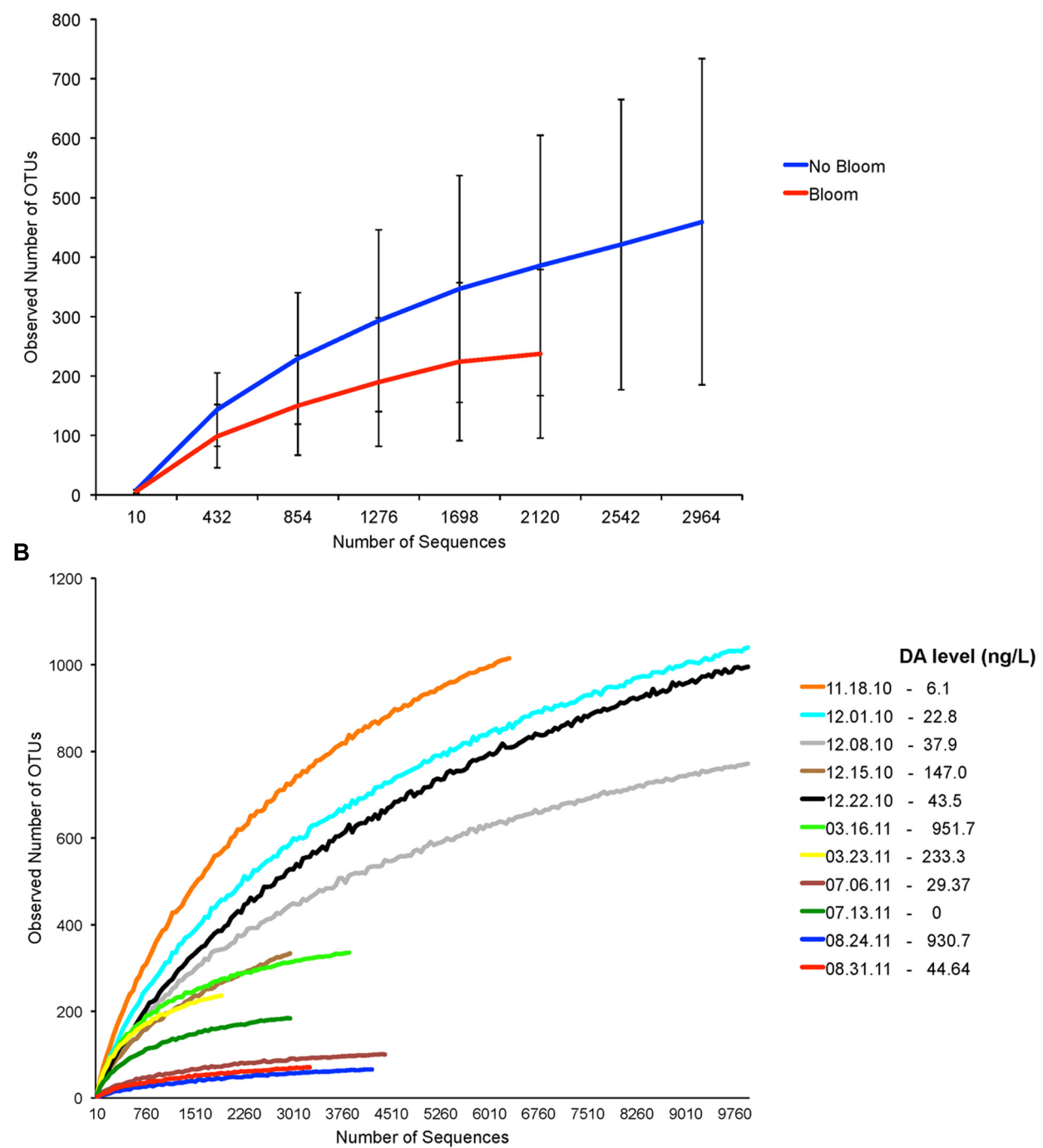

FIGURE 3 | Assessment of bacterial diversity based on number of Operational Taxonomic Units (OTUs) from samples before, during and after Pseudo-nitzschia bloom events in $\mathbf{2 0 1 0}$ and 2011. (A) Rarefaction curves generated from samples with no Pseudo-nitzschia bloom and Pseudo-nitzschia bloom. (B) Individual rarefaction curves generated for each sample. Particulate domoic acid level is shown for each sample in the legend. Low-toxin producer P. fraudulenta dominated in 2010 bloom while the high-toxin producer $P$. australis dominated in 2011 blooms.

was only present when there was low number of Pseudo-nitzschia cells in the water (in 2011) (Spearman rho $=0.67, p<0.02$ ). The presence of the very low abundant group Verrucomicrobia (1-4\%) and Planctomycetes (0-1\%) were not correlated with any of the aforementioned environmental parameters.

At the genus level, Vibrio spp. was the Gamma-proteobacteria that dominated the Pseudo-nitzschia bloom in 2010 (Figure 4B). Vibrio increased in relative abundance (6-65\%) as the bloom of Pseudo-nitzschia progressed into its peak, and positively correlated with the increase of $P$. fraudulenta cells, the abundant Pseudo-nitzschia species in 2010 bloom (Spearman rho $=0.8913, p<0.0002$ ). Vibrio was also positively influenced by phytoplankton biomass (chl) (Spearman rho $=0.78$, $p<0.004$ ) but it did not dominate in P. australis bloom in 2011.
Planococcus spp. (12-93\%), bacteria from the Firmicutes group, was positively correlated with the bloom of $P$. australis in 2011 (Spearman rho $=0.60, p<0.05$ ), where it dominated in three independent $P$. australis blooms. Temperature might have also significantly influenced its dominance (Spearman rho $=0.7426$, $p<0.009$ ).

Shewanella (1-27\%), the third most abundant bacteria in the samples, is an Alpha-proteobacteria that was present in 2010 bloom and showed positive correlations with $P$. fraudulenta (Spearman rho $=0.90, p<0.0002$ ), together with nitrate and phosphate (Spearman rho $=0.84$ and 0.71, $p<0.01$ ). Erythrobacter (0-8\%), another Alpha-proteobacteria, was present only in 2011 blooms and was negatively correlated with nitrate and ammonium (Spearman rho $=-0.78$ and $-0.68, p<0.03$ ). 


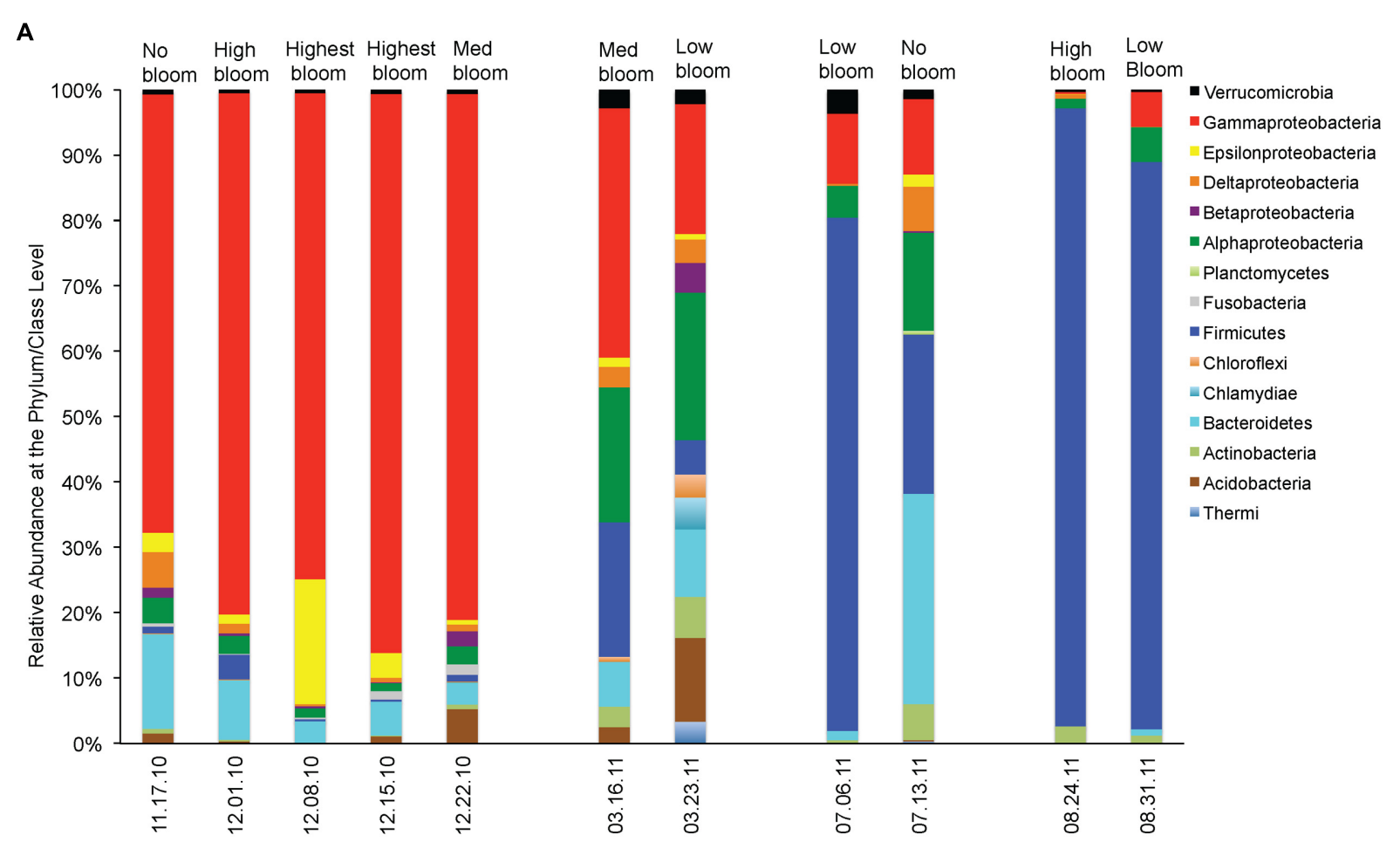

B



FIGURE 4 | Relative abundances of phytoplankton-associated bacteria before, during and after Pseudo-nitzschia bloom events in 2010 and 2011. (A) Relative abundance of bacteria at the phylum/ class level. (B) Relative abundance of bacteria at the Genus level. 
The abundant Gamma-proteobacteria bacteria, Psychromonas (1-21\%), was mostly seen in 2010 and its presence was not significantly influenced by any of the environmental variable studied other than $P$. fraudulenta cell number (Spearman rho $=0.65, p<0.03)$. Psychrobacter (0-9\%), another Gammaproteobacteria, was ubiquitous in many samples but was not specifically influenced by any of the environmental variables. The Lutimonas bacteria and other Flavobacteriaceae (0-10\%) also did not show any correlations with any of the environmental variables. Rubricoccus (0-18\%), another Bacteroidetes, showed positive correlation with temperature (Spearman rho $=0.62$, $p<0.04)$. The Epsilonbacteria, Arcobacter (0.4-19\%), was abundant in 2010 blooms and was positively correlated with $P$. fraudulenta and nitrate (Spearman rho $=0.85$ and 0.67 , $p<0.02$, respectively).

\section{DISCUSSION}

This study followed phytoplankton-associated bacterial community composition and succession from four natural Pseudo-nitzschia blooms in the same biogeographical location sampled before, during and after bloom and looked at how harmful algal bloom species and phytotoxin, domoic acid, influence phytoplankton-associated bacterial communities. Our study showed that the composition of the bacterial communities is driven by the phytoplankton species that comprised the bloom, while some less-abundant bacterial genera are also driven by phytoplankton biomass, temperature and nutrients (specifically nitrate and phosphate). Two species of Pseudo-nitzschia were found to dominate in the four bloom events, with the low-DA producing $P$. fraudulenta dominating in late Fall 2010 bloom (with a mix of small numbers of $P$. australis), and the high-DA producing $P$. australis dominating in three blooms in the spring, mid-summer and late summer of 2011. The dominant bacterial group changed with the dominant algal species that comprised the algal bloom. Moreover, with each bloom phase shift (increasing or decreasing of Pseudo-nitzschia cell numbers), these dominant bacterial groups also followed the same trend with the algal shift, that is high $P$. fraudulenta or $P$. australis cell number also increased the abundance of the respective dominant bacterial group. In this study, our approach did not allow us to study the composition of the bacterial community associated to a specific algal species but rather from a community of phytoplankton species that was dominated by Pseudonitzschia during bloom events. The Gamma-proteobacteria Vibrio spp., for instance, increased in relative abundance as $P$. fraudulenta cells increased in number, while the Firmicutes bacteria, Planoccocus spp. decreased in abundance as $P$. australis decreased in abundance. Vibrio spp. are known to associate with phytoplankton and zooplankton (Tamplin et al., 1990; Hsieh et al., 2007; Main et al., 2015) while Planococcus spp. are often isolated from Pseudo-nitzschia and are reported to be members of Pseudo-nitzschia microbiome (Sison-Mangus et al., 2014).

We also observed that when $P$. australis were replaced or co-dominated by other diatoms (Chaetoceros, Eucampia) or dinoflagellates (Guinardia, Protoperidinium), the bacteria Planococcus spp. was also replaced or co-dominated by the abundance of other bacterial groups from Bacteroidetes, Gammaand Alpha-proteobacteria. This suggests that specific bacteria and phytoplankton groups can influence each other and their abundance does not only depend on phytoplankton biomass abundance during bloom but that the relationship can also be dictated by the diversity of algal species in the phytoplankton community. Rooney-Varga et al. (2005) have reported similar findings where the phytoplankton community is responsible for the significant amount of variability in the attached-bacterial community composition. Just like in their study, we did not see any correlation between bacterial diversity and phytoplankton biomass (i.e., chlorophyll $a$, Table 1), hence a closer look at the phytoplankton species composition during and after phytoplankton blooms is necessary if we want to understand the factors that facilitate the dominance of phytoplanktonassociated bacterial groups and their role in the degradation of phytoplankton-derived organic matter.

Temperature, nitrate and phosphate seem to play a role in facilitating the abundance of some bacterial groups, but our data set is not enough to resolve if these abiotic factors can drive bacterial succession. Indeed, these physical factors affect the metabolism of phytoplankton and influences algal growth, which ultimately can influence phytoplankton-associated bacterial composition and diversity. In our study, we found no correlation between phytoplankton biomass, Pseudo-nitzschia cell number, nutrients (urea, ammonium, phosphate, silicate) and temperature, but nitrate and temperature did show negative correlation. Hence, a longer time series is suggested to give sufficient evidence to confirm the direct influence of these physical factors on bacterial community composition and succession.

Our current study showed that the neurotoxin domoic acid tend to limit bacterial diversity or bacterial OTU richness. For instance, the abundance of high-DA producing $P$. australis depressed bacterial diversity when it dominated the bloom in 2011. P. fraudulenta, a low-DA toxin producing Pseudonitzschia, also depressed bacterial diversity as DA increased when $P$. fraudulenta increased in cell number, but the bacteria diversity is not as low as that observed in $P$. australis bloom (Figure 3B). Interestingly, the presence of $P$. australis (albeit in small number), with P. fraudulenta in the December 15, 2010 bloom sample increased the DA level and drove the bacterial diversity further down (Figure 3B). These field-based results agreed with our past laboratory study, where we found a higher bacterial diversity harbored by cultured $P$. fraudulenta strains and a lower bacterial diversity in cultured $P$. australis strains (Sison-Mangus et al., 2014). This lends strong support to the idea that DA can structure Pseudo-nitzschia-associated bacterial communities. Domoic acid may act as a selective agent that can structure bacterial communities either by serving as a nutrient source for associated bacteria that can effectively assimilate DA or the toxin may act as deterrent to other associative bacteria. Previously, domoic acid has been hypothesized to be antibacterial (Bates et al., 1995) but concrete evidence is currently lacking to support this hypothesis. 
Current efforts are now focused on understanding which bacterial groups can degrade various types of phytoplanktonderived organic matter. The pervading principle is that bacterial diversity and composition is largely driven by the availability of organic material from phytoplankton biomass, and the bacteria that can degrade this copious amount of algal-derived organic material will get selected and proliferate in the marine environment. Landa et al. (2016), for instance, reported that bacterial groups traditionally known for being algal bloomassociated, have dominated the pool of enriched bacterial groups observed from artificially iron-induced phytoplankton blooms in the Southern Ocean. Recent studies have also looked at the genome of free-living bacteria that are dominant during phytoplankton bloom, which comprises mostly of Flavobacteriaceae, Roseobacters and Gamma-proteobacteria to determine their genetic capability of degrading phytoplanktonderived material (Teeling et al., 2012, 2016; Klindworth et al., 2014). We can use the same argument on the selection process undergone by bacterial groups that develop an associative lifestyle with phytoplankton. Associated bacteria are proximally at an advantage to readily access phytoplankton exudates when the algal host secretes them and can access the algal organic material for consumption once the host cell is dead, a niche filled by copiotrophic bacteria that may have led to the observation that attached bacteria are distinct and showed little to high diversity than free-living bacteria (Delong et al., 1993; Acinas et al., 1999; Mohit et al., 2014). Association of bacteria with phytoplankton can evolve into mutualistic partnership such as that observed between Sulfitobacter and P. multiseries (Amin et al., 2015) or to commensal-parasitic relationship between Phaeobacter and Emiliania huxleyi (Seyedsayamdost et al., 2011), or host-specificity between Pseudo-nitzschia and its microbiome (Sison-Mangus et al., 2014). To understand the evolution

\section{REFERENCES}

Acinas, S. G., Anton, J., and Rodriguez-Valera, F. (1999). Diversity of free-living and attached bacteria in offshore western Mediterranean waters as depicted by analysis of genes encoding 16S rRNA. Appl. Environ. Microbiol. 65, 514-522.

Altschul, S. F., Gish, W., Miller, W., Myers, E. W., and Lipman, D. J. (1990). Basic local alignment search tool. J. Mol. Biol. 215, 403-410. doi: 10.1016/S00222836(05)80360-2

Amin, S. A., Green, D. H., Hart, M. C., Kupper, F. C., Sunda, W. G., and Carrano, C. J. (2009). Photolysis of iron-siderophore chelates promotes bacterial-algal mutualism. Proc. Nat. Acad. Sci. U.S.A. 106, 17071-17076. doi: 10.1073/pnas.0905512106

Amin, S. A., Hmelo, L. R., van Tol, H. M., Durham, B. P., Carlson, L. T., Heal, K. R., et al. (2015). Interaction and signalling between a cosmopolitan phytoplankton and associated bacteria. Nature 522, 98-101. doi: 10.1038/nature14488

Azam, F., Fenchel, T., Field, J. G., Gray, J. S., Meyerreil, L. A., and Thingstad, F. (1983). The ecological role of water-column microbes in the sea. Mar. Ecol. Progr. Ser. 10, 257-263. doi: 10.3354/meps010257

Bates, S. S., Douglas, D. J., Doucette, G. J., and Leger, C. (1995). Enhancement of domoic acid production by reintroducing bacteria to axenic cultures of the diatom Pseudo-nitzschia multiseries. Nat. Toxins 3, 428-435. doi: 10.1002/nt.2620030605

Bates, S. S., Garrison, D. L., and Horner, R. A. (1998). "Bloom dynamics and physiology of domoic acid-producing Pseudo-nitzschia species," in Physiological of attached lifestyle among phytoplankton-associated bacteria, comparative genome analysis complemented with physiological and biochemical approaches are inviting if we want to gain a mechanistic insight of their evolutionary strategy. Similarly, field-based studies complemented with laboratory manipulations are required to understand the various influences of associated bacteria on phytoplankton physiology such as those related to toxin production, organic material production and recycling and algal bloom formation.

\section{AUTHOR CONTRIBUTIONS}

MSM and SJ conceived the project. MSM and RK executed the project, MSM and SM did the data analysis. MSM, SJ, and RK wrote the paper.

\section{FUNDING}

The National Science Foundation OCE 1131770 to SJ supported this work. MSM would like to thank UC-PPFP for fellowship support during her postdoc. STEM Diversity Program funded SM. Collection of environmental data from the Santa Cruz Municipal Wharf was supported by Cal-PReEMPT with funding from the NOAA-MERHAB program (Grant no. NA04NOS4780239, MERHAB \#194).

\section{ACKNOWLEDGMENT}

We gratefully thank Kendra Negrey for providing plankton tow samples and Keah Ying Lim for assistance with sample processing.

Ecology of Harmfull Algal Blooms, eds D. M. Anderson, A. D. Cembella, and G. M. Hallegraeff (Heidelberg: Springer-Verlag), 267-292.

Bidle, K. D., and Azam, F. (1999). Accelerated dissolution of diatom silica by marine bacterial assemblages. Nature 397, 508-512. doi: 10.1038/17351

Bjornsen, P. K. (1988). Phytoplankton exudation of organic matter: why do healthy cells do it. Limnol. Oceanogr. 33, 151-154. doi: 10.4319/lo.1988.33.1.0151

Buchan, A., LeCleir, G. R., Gulvik, C. A., and Gonzalez, J. M. (2014). Master recyclers: features and functions of bacteria associated with phytoplankton blooms. Nat. Rev. Microbiol. 12, 686-698. doi: 10.1038/nrmicro 3326

Buck, K. R., Uttalcooke, L., Pilskaln, C. H., Roelke, D. L., Villac, M. C., Fryxell, G. A., et al. (1992). Autecology of the Diatom Pseudonitzschia-Australis, a domoic acid producer, from monterey bay, California. Mar. Ecol. Prog. Ser. 84, 293-302. doi: 10.3354/meps084293

Caporaso, J. G., Bittinger, K., Bushman, F. D., DeSantis, T. Z., Andersen, G. L., and Knight, R. (2010a). PyNAST: a flexible tool for aligning sequences to a template alignment. Bioinformatics 26, 266-267. doi: 10.1093/bioinformatics/btp636

Caporaso, J. G., Kuczynski, J., Stombaugh, J., Bittinger, K., Bushman, F. D., Costello, E. K., et al. (2010b). QIIME allows analysis of highthroughput community sequencing data. Nat. Methods 7, 335-336. doi: 10.1038/nmeth.f.303

Croft, M. T., Lawrence, A. D., Raux-Deery, E., Warren, M. J., and Smith, A. G. (2005). Algae acquire vitamin B12 through a symbiotic relationship with bacteria. Nature 438, 90-93. doi: 10.1038/nature04056 
Delong, E. F., Franks, D. G., and Alldredge, A. L. (1993). Phylogenetic diversity of aggregate-attached vs free-living marine bacterial assemblages. Limnol. Oceanogr. 38, 924-934. doi: 10.4319/lo.1993.38.5.0924

DeSantis, T. Z., Hugenholtz, P., Larsen, N., Rojas, M., Brodie, E. L., Keller, K., et al. (2006). Greengenes, a chimera-checked 16S rRNA gene database and workbench compatible with ARB. Appl. Environ. Microbiol. 72, 5069-5072. doi: 10.1128/AEM.03006-05

Doucette, G. J., Kodama, M., Franca, S., and Gallacher, S. (1998). "Bacterial interactions with harmful algal bloom species: bloom ecology, toxigenesis, and cytology," in Physiological Ecology of Harmful Algal Blooms. NATO ASI Series 41, eds D. M. Anderson, A. D. Cembella, and G. M. Hallegraeff (Berlin: Springer), 619-647.

Edgar, R. C. (2010). Search and clustering orders of magnitude faster than BLAST. Bioinformatics 26, 2460-2461. doi: 10.1093/bioinformatics/btq461

Fischer, A. M., Ryan, J. P., Levesque, C., and Welschmeyer, N. (2014). Characterizing estuarine plume discharge into the coastal ocean using fatty acid biomarkers and pigment analysis. Mar. Environ. Res. 99, 106-116. doi: 10.1016/j.marenvres.2014.04.006

Gardes, A., Iversen, M. H., Grossart, H. P., Passow, U., and Ullrich, M. S. (2011). Diatom-associated bacteria are required for aggregation of Thalassiosira weissflogii. ISME J. 5, 436-445. doi: 10.1038/ismej.2010.145

Gontcharova, V., Youn, E., Wolcott, R. D., Hollister, E. B., Gentry, T. J., and Dowd, S. E. (2010). Black box chimera check (B2C2): a windows-based software for batch depletion of chimeras from bacterial 16S rRNA gene datasets. Open Microbiol. J. 4, 47-52. doi: 10.2174/1874285801004010047

Grossart, H. P., Levold, F., Allgaier, M., Simon, M., and Brinkhoff, T. (2005). Marine diatom species harbour distinct bacterial communities. Environ. Microbiol. 7, 860-873. doi: 10.1111/j.1462-2920.2005.00759.x

Hellebust, J. A. (1980). Citation classic - Excretion of some organic-compounds by marine-phytoplankton. Agric. Biol. Environ. Sci. 47:16.

Holmes, R. M., Aminot, A., Kérouel, R., Hooker, B. A. and Peterson, B. J., (1999). A simple and precise method for measuring ammonium in marine and freshwater ecosystems. Can. J. Fish. Aquat. Sci. 56, 1801-1808. doi: 10.1139/f99128

Hsieh, J. L., Fries, J. S., and Noble, R. T. (2007). Vibrio and phytoplankton dynamics during the summer of 2004 in a eutrophying estuary. Ecol. Appl. 17, S102-S109. doi: 10.1890/05-1274.1

Huse, S. M., Huber, J. A., Morrison, H. G., Sogin, M. L., and Mark Welch, D. (2007). Accuracy and quality of massively parallel DNA pyrosequencing. Genome Biol. 8:R143. doi: 10.1186/gb-2007-8-7-r143

Kaczmarska, I., Ehrman, J. M., Bates, S. S., Green, D. H., Leger, C., and Harris, J. (2005). Diversity and distribution of epibiotic bacteria on Pseudonitzschia multiseries (Bacillariophyceae) in culture, and comparison with those on diatoms in native seawater. Harmful Algae 4, 725-741. doi: 10.1016/j.hal.2004.10.001

Klindworth, A., Mann, A. J., Huang, S., Wichels, A., Quast, C., Waldmann, J., et al. (2014). Diversity and activity of marine bacterioplankton during a diatom bloom in the North Sea assessed by total RNA and pyrotag sequencing. Mar. Genomics 18 (Pt. B), 185-192. doi: 10.1016/j.margen.2014.08.007

Knepel, K., and Bogren, K. (2002). Determination of Orthophosphate by Flow Injection Analysis: Quikchemr Method 31-115-01-1-H. Milwaukee, WI: Lachat Instruments, 14.

Kudela, R. M., and Chavez, F. P. (2004). The impact of coastal runoff on ocean color during an El Niño year in central California. Deep Sea Res. Part II Top. Stud. Oceanogr. 51, 1173-1185. doi: 10.1016/S0967-0645(04)00106-7

Kudela, R. M., Lane, J. Q., and Cochlan, W. P. (2008). The potential role of anthropogenically derived nitrogen in the growth of harmful algae in California, USA. Harmful Algae 8, 103-110. doi: 10.1016/j.hal.2008.08.019

Landa, M., Blain, S., Christaki, U., Monchy, S., and Obernosterer, I. (2016). Shifts in bacterial community composition associated with increased carbon cycling in a mosaic of phytoplankton blooms. ISME J. 10, 39-50. doi: 10.1038/ismej.2015.105

Lane, J. Q., Raimondi, P. T., and Kudela, R. M. (2009). Development of a logistic regression model for the prediction of toxigenic Pseudo-nitzschia blooms in Monterey Bay, California. Mar. Ecol. Prog. Ser. 383, 37-51. doi: 10.3354/meps07999

Lane, J. Q., Roddam, C. M., Langlois, G. W., and Kudela, R. M. (2010). Application of solid phase adsorption toxin tracking (SPATT) for field detection of the hydrophilic phycotoxins domoic acid and saxitoxin in coastal California. Limnol. Oceanogr. Methods 8, 645-660. doi: 10.4319/lom.2010.8.0645

Larsson, U., and Hagstrom, A. (1979). Phytoplankton exudate release as an energy-source for the growth of pelagic bacteria. Mar. Biol. 52, 199-206. doi: 10.1007/BF00398133

Main, C. R., Salvitti, L. R., Whereat, E. B., and Coyne, K. J. (2015). Communitylevel and species-specific associations between phytoplankton and particleassociated Vibrio species in Delaware's Inland Bays. Appl. Environ. Microbiol. 81, 5703-5713. doi: 10.1128/AEM.00580-15

Mayali, X., and Azam, F. (2004). Algicidal bacteria in the sea and their impact on algal blooms. J. Eukaryot. Microbiol. 51, 139-144. doi: 10.1111/j.15507408.2004.tb00538.x

Mayali, X., Franks, P. J. S., and Burton, R. S. (2011). Temporal attachment dynamics by distinct bacterial taxa during a dinoflagellate bloom. Aquat. Microb. Ecol. 63, 111-122. doi: 10.3354/ame01483

Miller, P. E., and Scholin, C. A. (1998). Identification and enumeration of cultured and wild Pseudo-nitzschia (Bacillariophyceae) using species-specific LSU rRNAtargeted fluorescent probes and filter-based whole cell hybridization. J. Phycol. 34, 371-382. doi: 10.1046/j.1529-8817.1998.340371.x

Mohit, V., Archambault, P., Toupoint, N., and Lovejoy, C. (2014). Phylogenetic differences in attached and free-living bacterial communities in a temperate coastal lagoon during summer, revealed via high-throughput $16 \mathrm{~S}$ rRNA gene sequencing. Appl. Environ. Microbiol. 80, 2071-2083. doi: 10.1128/AEM. 02916-13

Pennington, J. T., and Chavez, F. P. (2000). Seasonal fluctuations of temperature, salinity and primary production at station H3/M1 over 1989-1996 in Monterey Bay, California. Deep Sea Res. Part II Top. Stud. Oceanogr. 47, 947-973. doi: 10.1016/S0967-0645(99)00132-0

Price, M. N., Dehal, P. S., and Arkin, A. P. (2010). FastTree 2-approximately maximum-likelihood trees for large alignments. PLOS ONE 5:e9490. doi: 10.1371/journal.pone.0009490

Price, N. M., and Harrison, P. J. (1987). Comparison of methods for the analysis of dissolved urea in seawater. Mar. Biol. 94, 307-317. doi: 10.1007/BF00392945

Reitan, K. I., Rainuzzo, J. R, and Olsen, Y. (1994). Effect of nutrient limitation on fatty acid and lipid content of marine microalgae. J. Phycol. 30, 972-979. doi: 10.1111/j.0022-3646.1994.00972.x

Riemann, L., Steward, G. F., and Azam, F. (2000). Dynamics of bacterial community composition and activity during a mesocosm diatom bloom. Appl. Environ. Microbiol. 66, 578-587. doi: 10.1128/AEM.66.2.578-587. 2000

Rooney-Varga, J. N., Giewat, M. W., Savin, M. C., Sood, S., LeGresley, M., and Martin, J. L. (2005). Links between phytoplankton and bacterial community dynamics in a coastal marine environment. Microb. Ecol. 49, 163-175. doi: 10.1007/s00248-003-1057-0

Schafer, H., Abbas, B., Witte, H., and Muyzer, G. (2002). Genetic diversity of 'satellite' bacteria present in cultures of marine diatoms. FEMS Microbiol. Ecol. 42, 25-35. doi: 10.1111/j.1574-6941.2002.tb00992.x

Scholin, C. A., Gulland, F., Doucette, G. J., Benson, S., Busman, M., Chavez, F. P., et al. (2000). Mortality of sea lions along the central California coast linked to a toxic diatom bloom. Nature 403, 80-84. doi: 10.1038/47481

Seyedsayamdost, M. R., Case, R. J., Kolter, R., and Clardy, J. (2011). The Jekylland-Hyde chemistry of Phaeobacter gallaeciensis. Nat. Chem. 3, 331-335. doi: 10.1038/nchem.1002

Sison-Mangus, M. P., Jiang, S., Tran, K. N., and Kudela, R. M. (2014). Host-specific adaptation governs the interaction of the marine diatom, Pseudo-nitzschia and their microbiota. ISME J. 8, 63-76. doi: 10.1038/ismej.2013.138

Skogsberg, T. (1936). Hydrography of Monterey Bay, California. Thermal conditions, 1929-1933. Trans. Am. Philos. Soc. 29, 1-152. doi: 10.2307/10 05510

Skogsberg, T., and Phelps, A. (1946). Hydrography of Monterey Bay, California. Thermal conditions, part II (1934-1937). Proc. Amer. Philos. Soc. 90, 350-386.

Smith, D. C., Steward, G. F., Long, R. A., and Azam, F. (1995). Bacterial mediation of carbon fluxes during a diatom bloom in a mesocosm. Deep Sea Res. Part II Top. Stud. Oceanogr. 42, 75-97. doi: 10.1016/0967-0645(95) 00005-B

Smith, P., and Bogren, K. (2001). Determination of Nitrate and/or Nitrite in Brackish or Seawater by Flow Injection Analysis Colorimeter: Quickchem Method 31-107-04-1-E. Milwaukee, WI: Lachat Instruments, 12. 
Smriga, S., Fernandez, V. I., Mitchell, J. G., and Stocker, R. (2016). Chemotaxis toward phytoplankton drives organic matter partitioning among marine bacteria. Proc. Natl. Acad. Sci. U.S.A. 113, 1576-1581. doi: 10.1073/pnas.1512307113

Tamplin, M. L., Gauzens, A. L., Huq, A., Sack, D. A., and Colwell, R. R. (1990). Attachment of Vibrio-cholerae eerogroup-O1 to zooplankton and phytoplankton of Bangladesh Waters. Appl. Environ. Microbiol. 56, 1977-1980.

Teeling, H., Fuchs, B. M., Becher, D., Klockow, C., Gardebrecht, A., Bennke, C. M., et al. (2012). Substrate-controlled succession of marine bacterioplankton populations induced by a phytoplankton bloom. Science 336, 608-611. doi: 10.1126/science. 1218344

Teeling, H., Fuchs, B. M., Bennke, C. M., Kruger, K., Chafee, M., Kappelmann, L., et al. (2016). Recurring patterns in bacterioplankton dynamics during coastal spring algae blooms. Elife 5:e11888. doi: 10.7554/eLife.11888

Wang, Q., Garrity, G. M., Tiedje, J. M., and Cole, J. R. (2007). Naive bayesian classifier for rapid assignment of rRNA sequences into the new bacterial taxonomy. Appl. Environ. Microbiol. 73, 5261-5267. doi: 10.1128/AEM. 00062-07
Welschmeyer, N. A. (1994). Fluorometric analysis of chlorophyll a in the presence of chlorophyll b and pheopigments. Limnol. Oceanogr. 39, 1985-1992. doi: 10.4319/lo.1994.39.8.1985

Wyllie, J. G., and Lynn, R. J. (1971). Distribution of temperature and salinity of 10 meters, 1960-69 and mean temperatures, salinity and oxygen at 150 meters, 1950-1968 in the California current. Calif. Coop. Ocean. Fish. Invest. Atlas 15, $1-188$.

Conflict of Interest Statement: The authors declare that the research was conducted in the absence of any commercial or financial relationships that could be construed as a potential conflict of interest.

Copyright (c) 2016 Sison-Mangus, Jiang, Kudela and Mehic. This is an open-access article distributed under the terms of the Creative Commons Attribution License (CC BY). The use, distribution or reproduction in other forums is permitted, provided the original author(s) or licensor are credited and that the original publication in this journal is cited, in accordance with accepted academic practice. No use, distribution or reproduction is permitted which does not comply with these terms. 